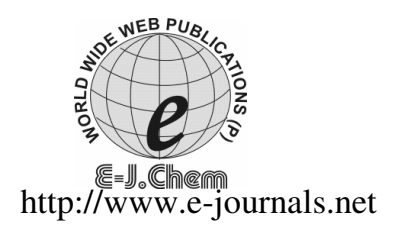

\title{
Statistical Study of Physicochemical Characteristics of Wastewater in Odogunyan, Lagos, Nigeria
}

\author{
I.S. AKOTEYON* ${ }^{*}$ and O. SOLADOYE \\ Department of Geography \& Planning \\ Lagos State University, Ojo, P.M.B.1087, Apapa, Lagos Nigeria \\ sewwyco@yahoo.com
}

Received 7 March 2010; Accepted 5 May 2010

\begin{abstract}
Physicochemical characteristics of wastewater samples collected from Odogunyan area was studied. Samples collected were designated $\left(\mathrm{OWS}_{1^{-}}\right.$ $\mathrm{OWS}_{5}$ ) representing 5 sampling points and were analyzed for 14 parameters including; ( $\mathrm{pH}$, TSS, TDS, Cl, EC, BOD, COD, DO, Pb, Cr, Cu, Hg, Fe and Zinc) during the month of September 2009. The mean value obtained for total suspended solid \& zinc were above FEPA stipulated tolerance limit in $\mathrm{OWS}_{2}$ \& $\mathrm{OWS}_{5}$ whereas for zinc, it was above the stipulated limit in $\mathrm{OWS}_{2}, \mathrm{OWS}_{3}$ and $\mathrm{OWS}_{5}$. Cr was not detected except in two locations (i.e. $\mathrm{OWS}_{3} \& \mathrm{OWS}_{5}$ ). Although there is no FEPA's limit for EC, the concentration obtained in $\mathrm{OWS}_{2}$ $\& \mathrm{OWS}_{5}$ were relatively higher than the mean obtained. Mercury and Lead were not detected in all the samples.
\end{abstract}

Keywords: Aquatic Environment, Effect, Industrial Effluent, Pollution

\section{Introduction}

The world's ever increasing population and her progressive adoption of an industrial based lifestyle has inevitably led to an increased anthropogenic impact on the biosphere. Due to rapid population growth, urbanization, industrialization and exploitation of natural resources, there has been a steady increase in the quantity, quality and diversity of discharges into the aquatic environment ${ }^{1}$. Although the industry constitutes an important factor for the economic growth, it may have negative effects on the natural environment when a sustainable development approach is not followed ${ }^{2-4}$.

Pollution and contamination of the aquatic environment in Nigeria is increasing in scope and magnitude. This could be attributed to the development of various types of industries, increase in population, especially in urban centers and inadequate consideration to environmental impact analysis of the various developmental projects ${ }^{5}$. According to a report $\mathrm{Etah}^{6}$, Nigeria generates over 500,000 tons of waste annually and industrial pollution is one of the major problems presently facing the country and effluents generated by the industries is one of the sources of pollution. 
Effluents from industries are associated with heavy disease burden ${ }^{7}$ and this could be part of the reasons for the current shorter life expectancy in the country ${ }^{8}$ when compared to the developed nations. Untreated effluent contains high concentrations of salts, total suspended solids, chemical oxygen demand, nitrogen and phosphorous and toxic compounds, such as heavy metal and chlorinated organic compounds ${ }^{9}$.Industrial effluents can seep into the aquifer and pollute groundwater or where it is discharged without proper treatment can affect the physicochemical properties of the receiving water and consequently its biota.

Metallic effluents for instance, can have ecological impacts on water bodies leading to increased nutrient load. These metals in effluent may increase fertility of the sediment and water column and consequently lead to eutrophication, which in open waters can progressively lead to oxygen deficiency, algal bloom and death of aquatic life. Water contaminated with metallic effluent can cause several health problems. Lead for instance, interfere with enzyme activities and formation of red blood cells, mercury may cause numbness, locomotor disorders, brain damage, convulsion and nervous problems ${ }^{10}$.

The geology of the study area is directly underlain by the benin formation which consists largely of sands / sandstones with lenses of shales and clays while the major river is the Ogun river. The population is about 200,000 people covering an area of about 30 hectares. Major human activity in the area is industrial-based with some subsistence farming. This study aimed at evaluating the effects of effluent wastewater on the aquatic environment.

\section{Experimental}

In this study, the industrial area of Odogunyan town in Ikorodu Local Government Area of Lagos State, Nigeria was selected. Five samples were collected from five sampling points. They are; $\mathrm{OWS}_{1}$ - control point (a natural stream around Odo-nla), $\mathrm{OWS}_{2}$-a collecting canal in Odo-nla, $\mathrm{OWS}_{3}$-drain from facility foot wear and Mayor Engineering Limited via Odokekere, $\mathrm{OWS}_{4}$-drain from Spintex textile mill, Odogunyan and $\mathrm{OWS}_{5}$-Parterzon Zoncheus(PZ),Odogunyan. In all, five samples i.e. one sample from each location was collected using a random sample technique (Figure 1).

\section{Sample collection}

The selected sampling area is noted for industrial activities and subsistence farming. The major sources of water supply include; stream, hand dug well and borehole. Wastewater samples were collected from 3 drain outlets (i.e.OWS $3-\mathrm{OWS}_{5}$ ) while $\mathrm{Ows}_{1}$ and $\mathrm{Ows}_{2}$ were from a natural stream far away from the industrial area and a channel connecting all the drainage in the area respectively.

Samples were collected in pre-cleaned plastic bottles with screw caps, placed in a cooler containing ice with necessary precautions.

\section{Analysis}

In situ measurements was carried out on; temperature, electrical conductivity and total dissolve solid using a portable-hand held HM digital COM-100, EC/TDS/temperature meter colour, turbidity and odour were determined through physical observation. The samples were taken to the laboratory for the determination of physical, chemical and biological parameters. These include total suspended solid, $\mathrm{pH}$, chlorde, biological oxygen demand, chemical oxygen demand, dissolve oxygen, lead, chromium, copper, mercury, iron and zinc. All samples were analyzed as described in the standard methods for the examination of wastewater ${ }^{11}$. Standard procedure involving spectrophotometer, photometry and titrimetry methods were used for the analysis. Results were compared with FEPA and BIS standards. 


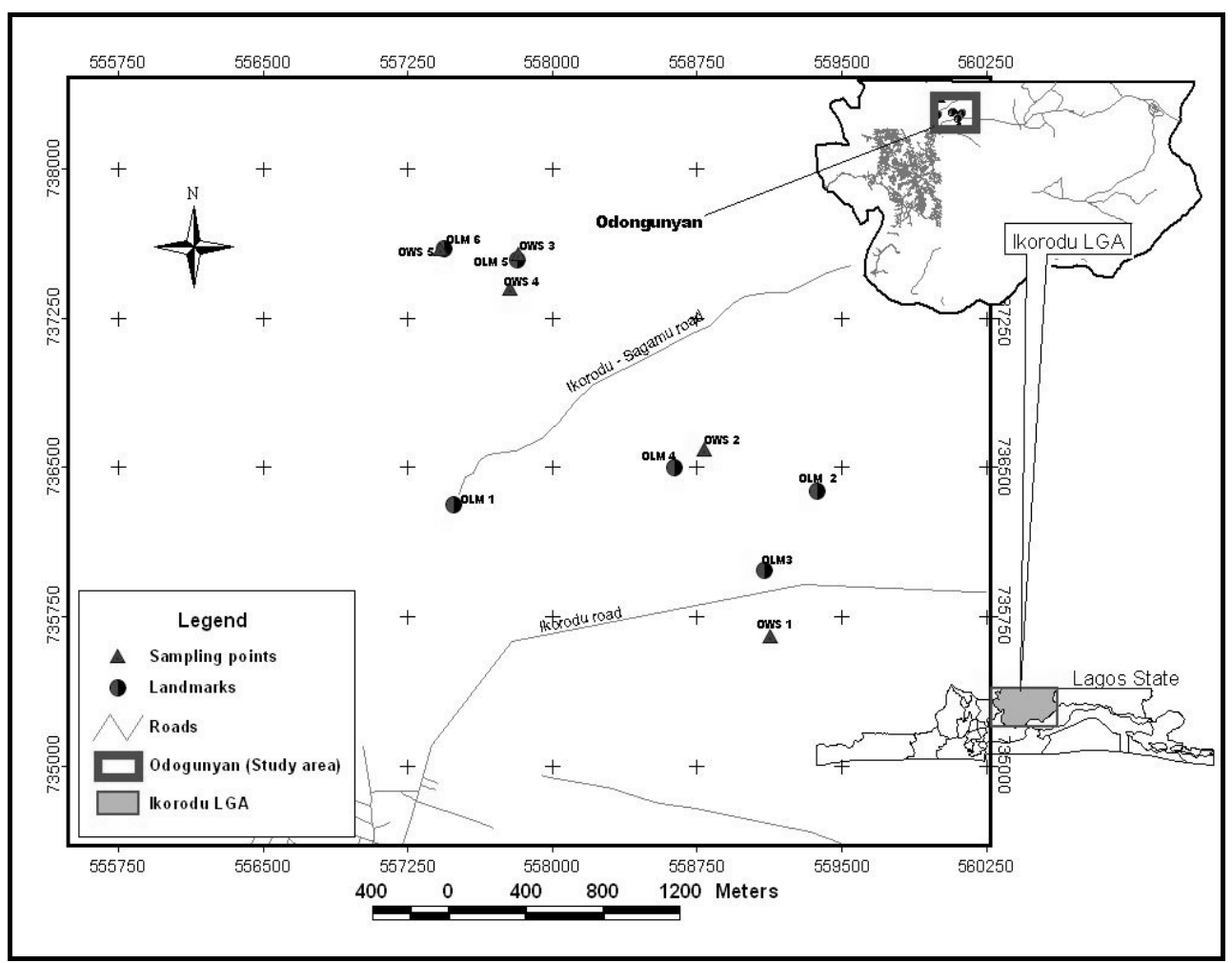

Figure 1. Sampling points in the study area

\section{Results and Discussion}

All the samples were from drains except the control point $\left(\mathrm{OWS}_{1}\right)$ which is a natural stream far from the industrial area. The physical and chemical/biological parameters are shown in Tables 1 and 2.

\section{Colour, turbidity, odour and temperature}

All the samples were coloured, turbid and have chocking and irritating odour except the control point indicating the presence of colloidal substances, suspended particles and decomposed material. The temperature of the samples ranges between 29 to $31{ }^{\circ} \mathrm{C}$.

Table 1. Physical parameters

\begin{tabular}{|c|c|c|c|c|c|}
\hline Parameter & $\mathrm{OWS}_{1}$ & $\mathrm{OWS}_{2}$ & $\mathrm{OWS}_{3}$ & $\mathrm{OWS}_{4}$ & $\mathrm{OWS}_{5}$ \\
\hline Temp., ${ }^{0} \mathrm{C}$ & 29.2 & 28.4 & 30.1 & 31.5 & 29.8 \\
\hline Colour & Colourless & Brownish & Grayish & Grayish & Brownish \\
\hline Odour & Odourless & $\begin{array}{l}\text { Chocking \& } \\
\text { irritating }\end{array}$ & irritating & irritating & $\begin{array}{l}\text { Detergent- } \\
\text { like }\end{array}$ \\
\hline Turbidity, mg/L & Clear & Not clear & Not clear & Not clear & Not clear \\
\hline TSS, mg/L & 3.0 & 115.0 & 12.0 & 7.0 & 140.0 \\
\hline $\mathrm{TDS}, \mathrm{mg} / \mathrm{L}$ & 58.9 & 156.0 & 88.3 & 61.6 & 303.0 \\
\hline $\mathrm{EC}, \mu \mathrm{scm}^{-1}$ & 115 & 301 & 151 & 121 & 585 \\
\hline
\end{tabular}


Table 2. Chemical and biological parameters

\begin{tabular}{cccccc}
\hline Parameter & $\mathrm{OWS}_{1}$ & $\mathrm{OWS}_{2}$ & $\mathrm{OWS}_{3}$ & $\mathrm{OWS}_{4}$ & $\mathrm{OWS}_{5}$ \\
\hline $\mathrm{pH}$ & 5.68 & 8.45 & 7.74 & 6.98 & 9.51 \\
$\mathrm{TSS}, \mathrm{mg} / \mathrm{L}$ & 3.0 & 115.0 & 12.0 & 7.0 & 140.0 \\
$\mathrm{DO}, \mathrm{mg} / \mathrm{L}$ & 5.2 & 4.9 & 3.1 & 3.8 & 3.2 \\
$\mathrm{BOD}^{20}, \mathrm{mg} / \mathrm{L}$ & 4.0 & 3.0 & 12.0 & 7.0 & 15.0 \\
$\mathrm{COD}, \mathrm{mg} / \mathrm{L}$ & 8.0 & 22.0 & 26.0 & 19.0 & 33.0 \\
$\mathrm{Chloride}, \mathrm{mg} / \mathrm{L}$ & 22.0 & 30.0 & 20.0 & 10.0 & 58.0 \\
$\mathrm{Cu}, \mathrm{mg} / \mathrm{L}$ & 0.06 & 0.15 & 0.23 & 0.08 & 0.19 \\
$\mathrm{Cr}, \mathrm{mg} / \mathrm{L}$ & $\mathrm{ND}$ & $\mathrm{ND}$ & 0.04 & $\mathrm{ND}$ & 0.10 \\
$\mathrm{Fe}, \mathrm{mg} / \mathrm{L}$ & 0.04 & 0.12 & 0.16 & 0.07 & 3.22 \\
$\mathrm{Hg}, \mathrm{mg} / \mathrm{L}$ & $\mathrm{ND}$ & $\mathrm{ND}$ & $\mathrm{ND}$ & $\mathrm{ND}$ & $\mathrm{ND}$ \\
$\mathrm{Pb}, \mathrm{mg} / \mathrm{L}$ & $\mathrm{ND}$ & $\mathrm{ND}$ & $\mathrm{ND}$ & $\mathrm{ND}$ & $\mathrm{ND}$ \\
$\mathrm{Zn}, \mathrm{mg} / \mathrm{L}$ & 0.76 & 2.41 & 2.30 & 0.95 & 6.11 \\
\hline
\end{tabular}

Source: fieldwork, 2009

\section{Electrical conductivity, total dissolve solid and total suspended solid}

Electrical conductivity varied between 115-585. Samples ows $_{2}$ and ows 5 had relatively higher conductivity which may be due to contamination by conducting material in the samples. According to the literature standards, TDS in all the wastewater samples were within the permissible limit. Concentration of TSS varied between 3.0-14.0. Samples ows $_{2}$ and ows ${ }_{5}$ had high values that exceed the permissible limits proposed by FEPA and BIS. The presence of excessive solids in water may be due to industrial and agricultural activities in the study area $^{14}$.

\section{Chemical and biological parameters}

The chemical and biological parameters are tabulated in Table 2. The wastewater samples have $\mathrm{pH}$ which varied between 5.68-9.51 and was well within the permissible limits of FEPA and BIS except in ows $_{5}$ which was slightly higher than the FEPA's standard. Dissolve oxygen in the samples were found to be in the range of 3.1-5.2 $\mathrm{mg} / \mathrm{L}$. Biological oxygen demand varied between 3.0-15.0 in all the samples and were well within the permissible limits of FEPA and BIS. BOD is an indication of the pollution strength of wastewaters. It also indicates that there could be low oxygen available for living organisms in the wastewater when utilizing the organic matter. Chemical oxygen demand range between 3.0-33.0 and all the samples were within the permissible limits of FEPA and BIS. COD imply toxic condition and the presence of biologically resistant organic substances ${ }^{15}$. Copper and iron concentrations in the samples varied between (10.0-58, 0.06-0.23 and 0.04-3.22 mg/L) respectively and were all within the permissible limits of FEPA and BIS. The accumulation of metals in an aquatic environment has direct consequences to man and to the ecosystem ${ }^{16}$. Chromium concentration varied between $0.04-0.10 \mathrm{mg} / \mathrm{L}$. Chromium was not detected in samples $\mathrm{OWS}_{1}, \mathrm{OWS}_{2}$ and $\mathrm{OWS}_{4}$. The concentration of zinc range between $0.76-6.11 \mathrm{mg} / \mathrm{L}$ and were found to be above FEPA standard. Sample $\mathrm{OWS}_{5}$ was relatively high among the samples.

Table 3 shows the descriptive statistics of wastewater samples. The pattern of relative variation of coefficient of variation shows that all the examined variables are heterogeneous except Iron and chromium the only homogenous parameters. For instance, $\mathrm{pH}(528.97 \%)$, dissolve oxygen $(416.49 \%)$ and chemical oxygen demand $(233.77 \%)$ were extremely high. 
Table 3. Descriptive statistics of wastewater analysis

\begin{tabular}{ccccc}
\hline Parameters & Mean & Std. Dev. & Variance & Coefficient of variation, \% \\
\hline pH & 7.67 & 1.45 & 2.11 & 528.97 \\
TSS & 55.40 & 66.49 & 4420.30 & 83.32 \\
DO & 4.04 & 0.97 & 0.93 & 416.49 \\
BOD & 8.20 & 5.17 & 26.70 & 158.61 \\
COD & 21.60 & 9.24 & 85.30 & 233.77 \\
Cl & 28.00 & 18.22 & 332.00 & 153.68 \\
Cu & 0.14 & 0.07 & 0.01 & 200.00 \\
Cr & 0.03 & 0.04 & 0.00 & 75.00 \\
Fe & 0.72 & 1.39 & 1.95 & 51.80 \\
Zn & 2.51 & 2.15 & 4.63 & 116.74 \\
TDS & 133.56 & 102.49 & 10503.58 & 130.32 \\
EC & 254.60 & 199.62 & 39846.80 & 127.54 \\
\hline
\end{tabular}

Source: fieldwork, 2009, Std.-standard Deviation

Correlation is the mutual relationship between two variables. Direct correlation exists when increase or decrease in the value of one parameter is associated with a corresponding increase or decrease in the value of the other. The correlation is said to be positive when increase in one parameter causes the increase in the other parameter and it is negative when increase in one parameter causes the decrease in the other parameter. The correlation coefficient ( $r$ ) has a value between +1 and -1 . Correlation is characterized as strong, when it is in the range of +0.8 to 1.0 and -0.8 to -1.0 , moderate if it is in the range of +0.5 to 0.8 and -0.5 to -0.8 and weak when it is in the range $\mathrm{e}^{17}$ of +0.0 to 0.5 and -0.0 to -0.5 .

The correlation coefficients (r) among various wastewater quality parameters were calculated and the values of the correlation coefficients (r) are given in Table 4. There is strong positive correlation between most of the parameters. For instance, TDS and EC (0.999), Zn and TDS (0.975), $\mathrm{Cl}$ and TDS/EC (0.968), Fe and $\mathrm{Zn}(0.947), \mathrm{pH}$ and COD (0.940), Cr and Zn (0.934) TSS and EC (0.923), BOD and Cr (0.919) were found. The correlation coefficients between $\mathrm{pH}$ and $\mathrm{Cl}(0.761)$, TSS and $\mathrm{Fe}(0.719)$, DO and COD (-0.799), BOD and COD (0.798), COD and TDS (0.778) were found to be moderate correlation. Dissolve oxygen was found with negative correlation with other parameters. $\mathrm{Cu}$ showed a weak correlation with other parameters.

Table 4. Relationship between wastewater quality parameters

\begin{tabular}{ccccccccccccc}
\hline Parameters & $\mathrm{pH}$ & $\mathrm{TSS}$ & $\mathrm{DO}$ & $\mathrm{BOD}$ & $\mathrm{COD}$ & $\mathrm{Cl}$ & $\mathrm{Cu}$ & $\mathrm{Cr}$ & $\mathrm{Fe}$ & $\mathrm{Zn}$ & $\mathrm{TDS}$ & $\mathrm{EC}$ \\
\hline $\mathrm{pH}$ & 1 & & & & & & & & & & & \\
TSS & 0.872 & 1 & & & & & & & & & & \\
$\mathrm{DO}$ & -0.550 & -0.110 & 1 & & & & & & & & & \\
$\mathrm{BOD}$ & 0.597 & 0.276 & -0.919 & 1 & & & & & & & & \\
$\mathrm{COD}$ & 0.940 & 0.666 & -0.799 & 0.798 & 1 & & & & & & & \\
$\mathrm{Cl}$ & 0.761 & 0.865 & -0.264 & 0.558 & 0.648 & 1 & & & & & & \\
$\mathrm{Cu}$ & 0.734 & 0.419 & -0.707 & 0.698 & 0.833 & 0.450 & 1 & & & & & \\
$\mathrm{Cr}$ & 0.733 & 0.577 & -0.718 & 0.919 & 0.813 & 0.839 & 0.660 & 1 & & & & \\
Fe & 0.726 & 0.719 & -0.504 & 0.749 & 0.712 & 0.924 & 0.403 & 0.928 & 1 & & & \\
Zn & 0.888 & 0.830 & -0.550 & 0.752 & 0.855 & 0.944 & 0.636 & 0.934 & 0.947 & 1 & & \\
TDS & 0.881 & 0.918 & -0.378 & 0.596 & 0.778 & 0.968 & 0.506 & 0.842 & 0.931 & 0.975 & 1 & \\
EC & 0.868 & 0.923 & -0.350 & 0.572 & 0.756 & 0.968 & 0.468 & 0.826 & 0.930 & 0.966 & 0.999 & 1 \\
\hline
\end{tabular}




\section{Conclusion}

The result obtained from this study showed that most of the physicochemical parameters studied were all within the desirable limit for effluent disposal on surface waters recommended by FEPA and BIS except for $\mathrm{Zn}, \mathrm{pH}$ and TSS. Also, it is important to note that effluent discharged from locations $\left(\mathrm{OWS}_{2}\right.$ and $\mathrm{OWS}_{5}$ ) were exceptionally high compared to other sampling locations. Results of the correlation analysis show that TDS and EC, $\mathrm{Zn}$ and TDS, $\mathrm{Cl}$ and TDS/EC, Fe and $\mathrm{Zn}, \mathrm{pH}$ and COD, $\mathrm{Cr}$ and $\mathrm{Zn}$, TSS and EC, BOD and $\mathrm{Cr}$ had high correlation with most of the other parameters. In view of this, there is need for routine monitoring of the effluents wastewater in the area and also the need for appropriate treatment of wastewater effluents before it is discharged unto the surrounding aquatic environment using best available technique (BAT).

\section{Acknowledgment}

We acknowledge the assistance of Mr. Bengusa Ben of the Department of Chemistry, University of Lagos, Akoka who carried out the analytical experiment of the wastewater samples.

\section{References}

1. Food and Agricultural Organization, African Fisheries and the Environment. F.A.O of the United Nations Regional Office for Africa Accra, 1991, RAFR/91/02. 26PP.

2. Casares M L, Ulierte N, Matarán A, Ramos A and Zamorano M, Waste Manage., 2005, 25, 1075-1082.

3. Tchobanoglous G, Thrisen H and Vigil S A, Integrated Waste Management, Madrid, Spain, McGraw-Hill, 1994, 48

4. Hao Zhang, Xiangrong Wang, Hon H Ho and Yi Yong, J Environ Manag., 2008, 88(4), 1047-1055

5. Hassan A S, The Effect of Nigerian National Petroleum Corporation (NNPC) Refinery Effluent on the Biota of Romi Stream, Kaduna, 1987, 31 -150.

6. Itah A Y, Creating Public Awareness in Environmental and Public Health Education: In The Proceedings of Teachers' Association (STAN), 1998, 186 - 189.

7. World Health Organization, Water Pollutants: Biological Agents Dissolved Chemicals, Non-dissolved Chemicals, Sediments, Heat, WHO CEHA, Amman, Jordan, 2002.

8. World Health Organization, WHO Report 2003: Shaping the Future, World Health Organization, 1211 Geneva 27, Switzerland, 2002.

9. Correia V M, Stephanson T and Judd S J, Environ Technol., 1994, 15, 917-929.

10. Asamudo N U, Dava AS and Ezeronye O U, African J Biotechnol., 2005, 4(13), 1548-1553.

11. American Public Health Association (APHA) Standard Methods for the Examination of Water and Wastewater, WEF and AWWA, $20^{\text {th }}$ Edition, USA, 1998,

12. Federal Environmental Protection Agency (FEPA), Guidelines to Standards for Environmental Pollution Control in Nigeria, 1991.

13. Bureau of Indian Standards (BIS), Standards for Disposal of Treated Effluents on Inland Surface Water, IS: 2490(I), Bureau of Indian Standards, New Delhi, 1981.

14. Kasthuri R, Lalitha S, Kalaivani D, Banumathi $\mathrm{K}$ and Nitha N, Indian J Environ Protect., 2005, 25(3), 245-248.

15. Sawyer C C and Mccarty P L, Chemistry for Environmental Engineers, McGraw Hill, New York, 1978, 331-514.

16. Oke L A, Okuofu C A and Otun J A, J Appl Sci Res., 2006, 2(4), 209-216.

17. Achuthan Nair, Abdullan G, Mohamad I and Mahamoud Mahdy Fadiel, Poll Res., 2005, 24(1), 1-6. 


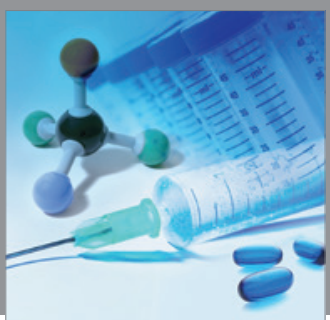

International Journal of

Medicinal Chemistry

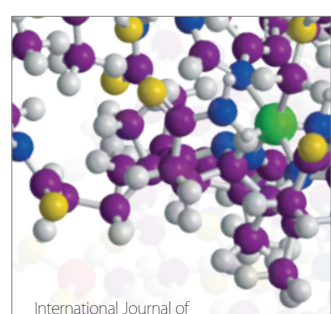

Carbohydrate Chemistry

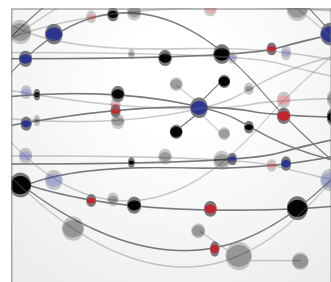

The Scientific World Journal
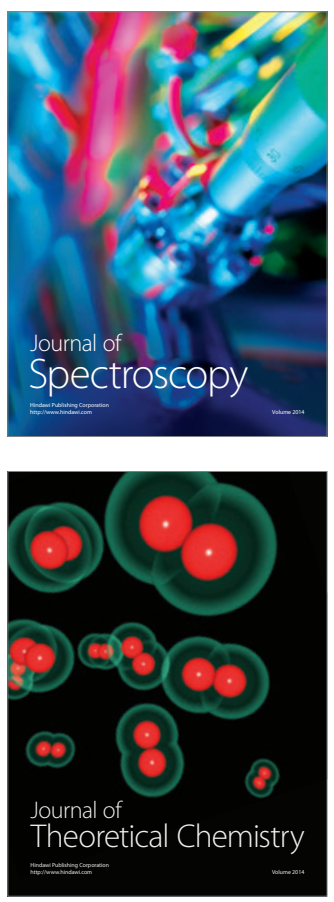
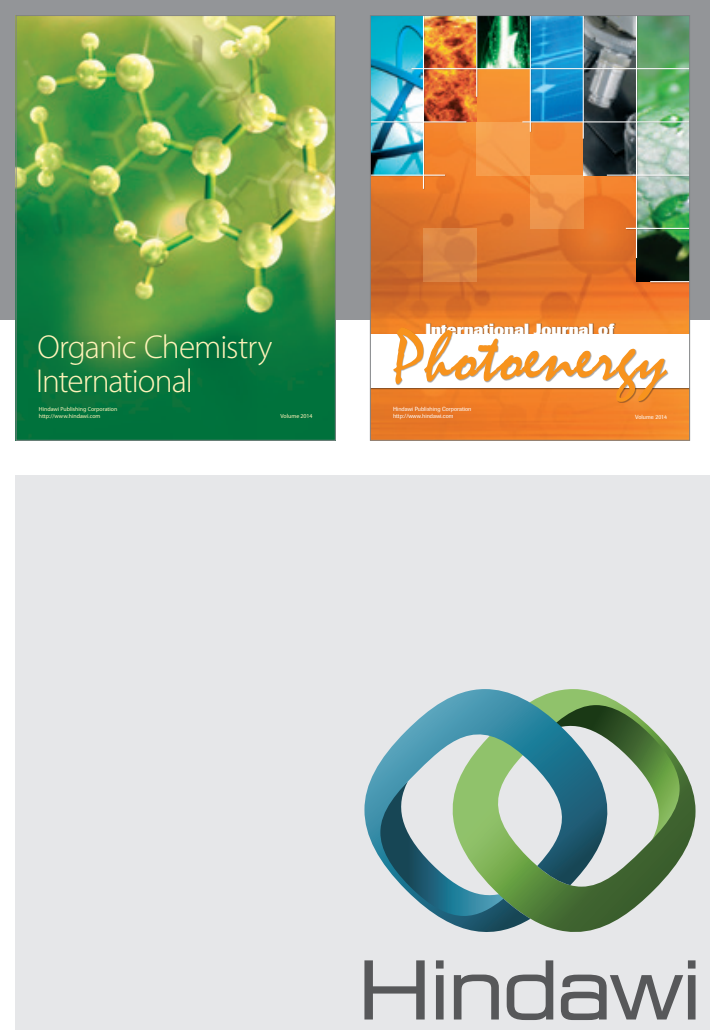

Submit your manuscripts at

http://www.hindawi.com
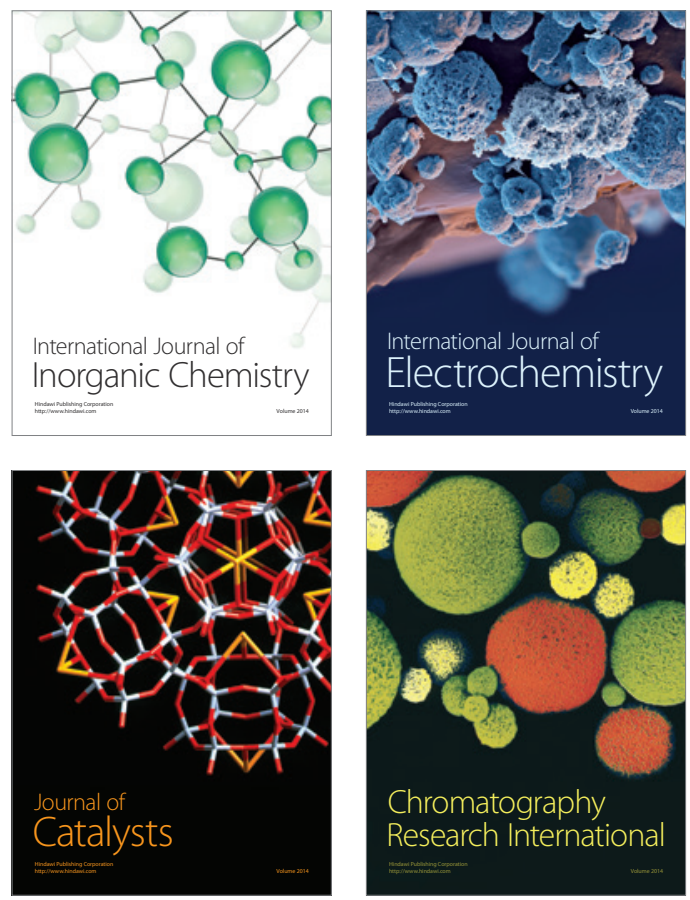
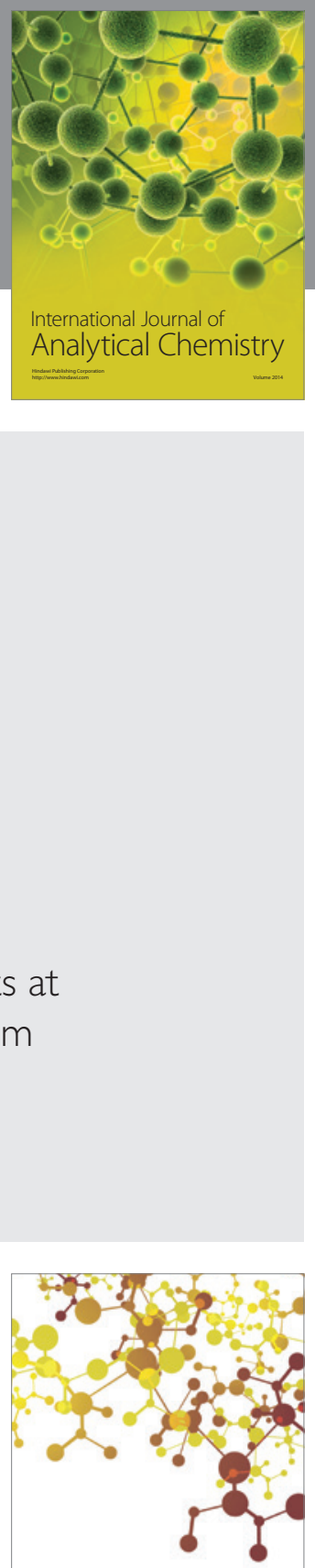

Journal of

Applied Chemistry
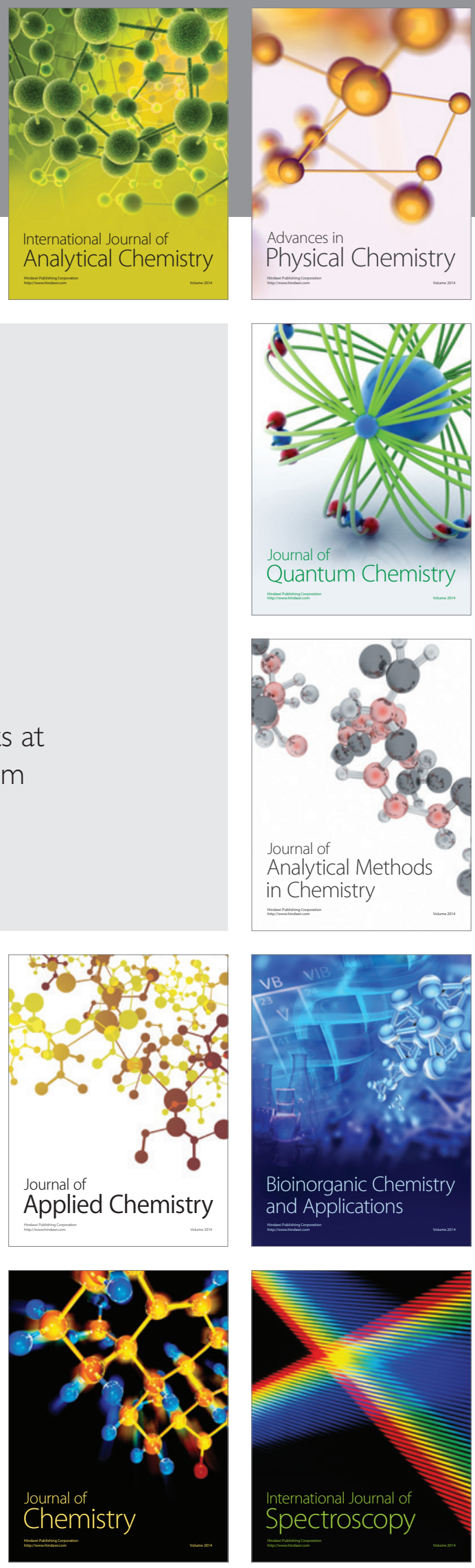